\title{
THE ACTUALIZATION OF LEADERSHIP MODELS ADOPTED BY FIELD IMPLEMENTERS THAT INFLUENCING THE CONTRACTOR EMPLOYEES' MOTIVATION AND PERFORMANCE
}

\author{
Dafid Irawan*, Indrasurya B. Mochtar, Christiono Utomo \\ Institut Teknologi Sepuluh November, Surabaya, Indonesia
}

The quality of foremen, handymen, and workers plays an important role in improving the building quality. In this case, field implementers should not only possess communication ability with their site engineers, site managers, and the workers, but also technical and managerial ability to make a direct relationship with the foremen, skilled handymen or blue-collar workers. From the organizational relationship, field implementers should be able to implement the work drawing with a certain method of implementation in order to create a building by optimizing the available resources. The objective of this present research is to test and analyze the actualization of the leadership model adopted by the field implementers in influencing the contractor employees' motivation and performance. This research was conducted in Contractors with grades 5, 6, and 7 in Malang, Surabaya, Blitar, and Probolinggo cities. The findings of this present research are as follows: (1) a combinational leadership significantly influenced the employees' performance; (2) work motivation significantly influenced the improvement of the employees' performance; (3) task- and personoriented leadership and liberalization leadership styles indirectly influenced the employees' performance through motivation. In the three relationships, the leadership position is very important since it would give great changes of employees' work motivation and performance.

Key words: leadership, motivation, employees' performance

\section{BACKGROUND}

The world condition in this 21 century has changed compared with that in the previous century due to the global financial crises and to the changes in the construction industry where at present many construction services companies join together in working on projects. Therefore, this needs project leaders who are able to implement the companies' vision-missions and to improve the team cooperation, communication, soft skills and transparency (Lloyd-Walker and Walker, 2011). According to Lloyd and Walker (2011), a great challenge a project leader encounters in order to be able to lead his organization sustainably in the future is that he should be able to make some adaptations to his environment to fulfill the changes of the needs in the 21 century.

According to Kaulio (2008), the leadership challenge is to survive and to keep sustainability, fulfill standards determined by the stakeholders and to satisfy the partners (clients, supervisors, and consultants), to maintain high motivation in groups, and to do any proper actions in line with the aim of the project. The task of the leadership in a project is not only to do any jobs dealing with the project, but also to ensure the group unity and wholeness, and to protect resources from any competitions. Muller and Turner (2007) also identified ten challenges of the leadership and the success in a project namely: the attainment of the project performance (function, budget, and time), stakeholders' satisfaction, users' satisfaction, suppliers' satisfaction, project team's satisfaction, the attainment of the users' purpose, fulfillment of the purpose of the project, the clients' satisfaction with the project results, the business continuation with the clients. Kloppenborg dan Petrick (1999) added that the challenges encountered by the leadership style needed for successful projects in the future are as follows: sincerity to one-self, supportive behavior, ability to maintain good relations with subordinates, and ability to make effective interactions with others.

According to Toor and Ofori (2008), a different approach to managing a project in the 21 century is needed since it requires different project leadership knowledge and skills, and this also in effect needs a new leadership style. Thite (2000) stated that no single leadership style will be effective in all project situations, but a flexible leadership style supported by organization is required.

Low motivation is often the main cause of the failure of a project. Motivation is considered as the main factor in the success of a project management (Verma, 1996). According to Turner et al (2009), besides work motivation, the existence of work de-motivation needs to be identified since it is a very important aspect in the construction service industry to support the company's business function.

Less motivated managers and employees tend to perform badly, although they have good knowledge in management and project and in technical skills (Germann, 2004). Oyedele (2010) identifies four empirical factors of motivation covering a project condition beneficial for working namely organizational support, the success in implementing the design and the effort for recognition.

Foster and Seeker (2001) stated that the causes of an employee's less performance is less knowledge and 
skills in doing the job given to him. Soekiman et all (2011) stated that a problem that often happens to productivity is the one dealing with an employee's performance.

Some researches on leadership and employees' performance have been conducted previously. A research made by Liridon Veliu et all (2017) on the managers of middle and high class private businesses in Kosovo showed that democratic, autocratic and transformational leadership styles gave positive effects on the employees' performance. Ali Orazi Sougui, et all (2015) also conducted a research on the employees in Telecommunication companies in Malaysia and the results showed that all leadership styles gave positive and negative effects on employees. Idah Naile and Jacob M Selesho (2017) in their research showed that a transformational leadership style may be employed to improve the organizational commitment and employees' performance.

The relationship between leadership and motivation has much been investigated. Mustaqim (2016) studying the employees in PT Garuda Sakti Artha Surabaya Indonesia found that a leadership style and motivation significantly influenced the employees' work satisfaction. A research conducted by Sudi Apak and Sefer Gumus (2015) on the administrative workers in Istanbul, Turkey showed that the application of disciplinary rules to all workers may improve their motivation. Moreover, there is no correlation between employees' socio-demographic characteristics (age, sex, education, length of work, position in the institution) and the types of leadership models in improving work motivation.

Ficke H. Rawung (2013) also studied the staffs in Manado State University and the results of the study showed that there is no significantly positive correlation between the leadership and work motivation. From a research conducted by Laura M. Graves and Joseph Sarkis (2018), it was also found that a transformational leadership style positively influenced the internal motivation when the employees possessed strong environmental values and transformational leadership that may create external motivation through the use of reward.

Dealing with employees' motivation and performance, Elizabeth and Kwesi (2015) showed that there is a significant correlation between intrinsic motivation and work achievement. Among the employees with high education level, intrinsic reward in the form of praise and recognition is more motivated. Moreover, employees/workers are more motivated with intrinsic and extrinsic rewards with the emphasis on reward/remuneration/salary, job security, health insurance, and pension scheme.

From the research conducted by Sara Ghaffari et al (2017), it was found that two most dominant factors of motivation in improving work achievement are first, responsibility and second, allowance. Thoni Setyo Prabowo, et al (2017) studying the employees of hotel Kartika Graha Malang, Indonesia, showed that work motivation plays an important role in improving the employees' perfor- mance and shows significantly positive influence.

A research made by Irum Shahzadi et al (2014) in either private or state faculty of teaching in Pakistan showed that there is a positive correlation between employees' motivation and their performance. Amjad Ali et al (2016) investigating the employees in Information and Technology companies in Pakistan showed that there is a positive influence of motivation on employees' motivation and work satisfaction that may improve individual and organizational ability.

From the descriptions above, there are many researches dealing with the relationship between leadership and employees' performance, between leadership and motivation and motivation and employees's' performance. But to best knowledge of the researchers, no research has been made on the contractor projects, especially in Indonesia. Therefore, it is necessary to study on the actualization of the leadership model of the field implementers in influencing the contractors employees' motivation and performance.

\section{REVIEW OF LITERATURE}

\section{Leadership}

Leadership according to Dubrin (2004) and Dansereau (1995) is defined as a process of influencing others so that they follow and agree with what is necessary to do and how the process may be conducted effectively and facilitate individuals and collective team to reach a common goal. The most common measure that may be used to understand a leadership effectiveness is how far an organization is able to apply its leadership successfully in doing its tasks or in reaching its goal. According to Yukl and Lepsinger (2005), leadership involves a social process in the form of intentional influence given by a person to others in the relationship structure of an activity, the group or organizational relationships. The followings will be described some types of leadership.

Transactional leadership explains how the needs of its followers will be satisfied in the exchange to complete their work. Therefore, this transactional leadership is based on the economic principles and shows that the followers rationally realize their needs. A transactional leader enforces the following behavior: situational rewards. A transactional leadership is an effect leadership if all followers are familiar with how to get respected rewards (Bono and Judge, 2004). According to the transformational leadership theory, the followers posses trust and respect to their leaders and they are motivated to do more and exceed what is usually expected to them. Transformational leaders enforce their leadership through four types of behavior: individual consideration, intellectual stimulation, idealism influence, and motivational inspiration. Charismatic leadership theories emphasize behavior to enable the leaders to have great influence to their followers (Yukl, 1999). Based on the characteristics of the situation, the followers symbolize 
their leaders to have extraordinary quality and charisma, a charisma which is based on the characteristic or symbol, so that the followers see the charisma on the basis of the observations on their leader's behavior so that it can be determined whether the leader may really be considered to be a charismatic leader.

An authentic leadership theory principally emphasizes the measure of a reciprocal approach to leadership. For instance, Avolio and Gardner (2005) discuss the importance of an authentic relationship between a leader and his followers that support the attainment of the common goal and development. Avolio et al (2004) showed that an authentic leader promotes his followers' optimism by first identifying that the interaction between a leader and his followers will result in leadership (Gardner, et al, 2005). An authentic leader causes a personal identification of its followers with their leader and a social identification with the group that at last may improve the followers' certain level of expectation, their positive emotional trust, and optimism. Avolio et al, (2004) and Ilies, et al, (2005) discusses the importance of the spread of position emotions, positive social exchanges, and supports from the followers and self-determination as a potential process where a leader-followers authenticity give effects on prosperity.

\section{Work motivation}

According to Sansone dan Harackiewicz (2000), motivation is from the word "movere", meaning "move", therefore, motivation is defined as one's inner control that is able to activate and lead behavior. The types of behavior and external needs show behavior motivated by a need or desire to reach certain results. Therefore, motivation gives energy and guides behavior to reach a certain goal (Sansone and Harackiewic, 2000).

Work motivation is a sets of energetic powers coming from internal or external individuals leading to focus on the management of a work to improve performance. Work motivation started to be investigated in the basic theories of motivation through Maslow's works (1954 covering: satisfaction, need for safety, affiliation and recognition. McClelland (1961) stated that motivation is influenced by the work characteristics, salary, collegiality, and autonomy. A conceptual understanding of this work motivation then bring out a work characteristic model (Hackman and Oldham, 1980). The importance of the roles of information documented would help employees do their tasks effectively has started to be studied (deTreville and Antonakis, 2006).

Some researchers conclude that without motivation, the most talented persons will not be able to show their potency and that motivated persons will not perform above their intelligence level and academic ability (Germann, 2004). Kerzner (2000) underlines the importance of the clarity of the goal to reach optimal project performance. Then, a project goal should be realistically determined by taking into account the available resources (Pinto,
2000). According to Colquitt (2001) and Rose and Manley (2011), to avoid or omit de-motivation factors in companiess, the following factors are suggested: justice and equality in resources distribution, justice in procedures, and justice in the obedience to rules and justice in the process and justice in the decisions leading to results, and justice in interactions (respect, dignity, politeness, and the like shown by the employees in their work place when they interact with others).

\section{Employees' performance}

Abdel-Razek (2007) stated that a proper measurement of employees' productivity may be used as an indicator that may be depended in improving the project employees' performance. Thomas and Tang, Ziwei (2010) stated that there are three determining factors in a project success, namely managerial performance, financial performance and employees' performance. The followings are presented some research models used to study employees.

According to Soekiman, et al (2011), a contractor company faced challenges dealing with productivity problems and the problems usually deal with employees' performance. The performance is influenced by many factors and is usually related to the time, cost and quality performance. Productivity in construction companies shows a rate of decline compared with that in other sectors (Bernstein, 2007). This is also the case in Indonesia. Efforts to reach better performance and improve productivity in the construction field need some understandings of various indicators of productivity as a way to understand a project's performance (Atkinson et al, 1997).

\section{RESEARCH METHODOLOGY}

Indicators of the leadership variables of the field implementers, motivation, and employees' performance are identified. Indicators of the variables obtained based on the results of the pervious researches taking attention to the relationship and the influence of leadership to motivation and performance of the foremen, handymen, and workers are among others: leadership (Lloyd and Walker, 20Il; Toor and Ofori, 2008; Avolio and Gardner, 2005), motivation (Oyedele, 2012; Rose and Manley, 2011; Mueller and Turner, 2009), and employees' performance (Hyvari, 2006; Irawan et. al., 2012; Soekiman et. al., 2011). The data were obtained from the respondents through the improved questionnaires and interviews with respondents consisting of the field implementers and foremen, handymen and workers in the contractors grades 5,6 , and 7 . They were asked to respond to the questionnaires to obtain information about: the influence of the leadership of the field implementers to employees' motivation and performance. An evaluation was made using a Likert Scale with the order from 1 to 5 representing very disagree, disagree, quite disagree, agree, and very agree, respectively.

The research site is Malang, Surabaya, Blitar, and 
Probolinggo cities where the number of contractors taken in this research was 53 contractor companies. The secondary data were taken from the list of contractors with grades 5, 6, and 7 obtained from the local Association of the Contractor Services Company, while the respondents were the field implementers, foremen, handymen and workers. From each company, three respondents namely foremen, handymen, and workers were taken, so the total number of the respondents are 159.

In the application of the SEM-PLS model, according to Hair et al (2014), it is estimated that the number of sample should be 10 times the number of the latent variable. In the hypothetical model, there are 7 variables of which the two are work motivation with 6 indicators and employees' performance with 5 indicators. Therefore, the total number of the latent variable is 16 . From the calculation, the number of the needed samples is 160 respondents.

The objective of this present research is to analyze the influence of the field implementers' leadership on employees' motivation and work performance (foremen, handymen, and workers). The model of the relationship among the variables was analyzed using the SEM (Structural Equation Modeling. Schematically, this modeling concept is presented in Figure 1.

The model was tested using the Structural Equation Modeling with a partial Least Square (SEM-PLS) approach. It is a multivariate technique combining a multi- variate regression and a factorial analysis to explain the relationship among some variables (Hair, 2006). In the SEM-PLS, the measurement model is called the outer model, while the structural model is called the inner model. In the five leadership variables, the outer model is first order in nature since it does not have any indicators or the direct variables are constructed by the items. Meanwhile, in the work motivation and employee' performance variables, the outer model is the second order in nature, since it does not have any indicators or the variables constructed by the items of the indicators and from the indicators to the variables.

This model is very complex but in the SEM-PLS, there are not many assumptions and requirements in the analysis. The SEM-PLS has some superiorities than other analysis tools since (1) it may analyze complex models; (2) the data should not be normally distributed; (3) it may use small samples and (4) it may handle missing value.

The use of the PLS as a method of analysis requires some steps in the structural equation modeling. The steps of the PLS may be described as follows:

1. Designing a structural model (inner model) namely designing the relationship among variables (constructs) based on the research hypotheses (see Figure 2)

2. Designing a measurement model (outer model) namely designing the relationship between the la-

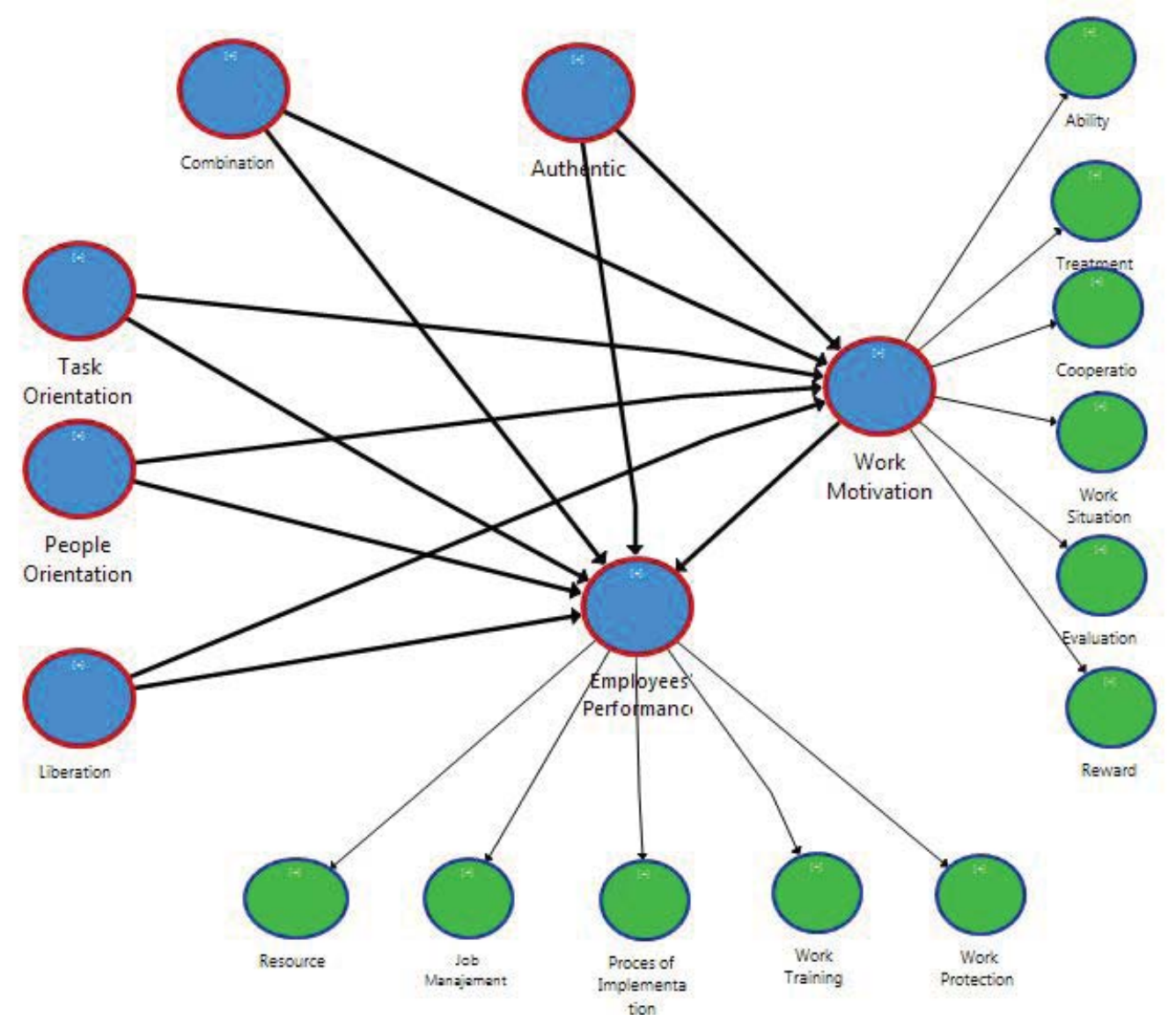

Figure 1: Leadership, and Employees' Motivation and Performance Modeling 
tent variable and its indicators. This present research employed reflective indicators, since the existence of the indicators are determined by the construct or each indicator should capture the essence of its construct domain and the relationship among the research indicators possesses a high covariance (Hartono and Abdillah, 2009). In the reflective model, each change in one indicator will cause a change in another indicator or each indicator has a correlation with other indicators.

3. Constructing a path diagram.

4. At this stage, a path diagram showing the relationship among latent variables (constructs) either exogenous or endogenous ones is created.

5. Converting the path diagram into the equation system.

The equation showing the relationship between the latent variable (inner model) and the relationship between the indicators and their variables (outer model) is conducted. The Partial Least Square (PLS) analysis is made through two stages namely evaluating the outer model and the inner model. Outer model is a measurement model to value the validity and reliability of the construct (Hartono and Abdillah, 2009). A reliability test is used to measure the internal consistence of the measuring tool. Reliability shows accuracy, consistency, and fidelity of a measuring tool in doing measurement. An instrument is considered to be reliable if the values of the Cronbach's Alpha and Composite Reliability are higher than or equivalent with 0.60 (Hartono and Abdillah, 2009).

The second stage in the PLS analysis is to evaluate the inner model to understand the coefficient $R^{2}$ for the dependent construct and the t-statistic value to test the construct significance in the structural model (Hartono dan Abdillah, 2009; Ghozali, 2011). The estimation value for the path relationship in the structural model is obtained through bootstrapping. This present research employed 500 bootstrapping processes, since the number of the sample exceeds the minimal limit required in the PLS analysis.

In testing the mediation effects, the significance test may be seen in the table of the total influence (Hartono and Abdillah, 2009). This is caused by the mediation influence which is the combination between the results of the direct and indirect influences of the dependent variables on the dependent ones. The testing of the mediation ifluences may be made if the independent variables have direct influences on the dependent variables (Baron and Kenny, 1986; Hair et al, 2010). In the result of the running software SmartPLS, the results of the direct and indirect effects have been provided. The indirect influences that would be proved in this present research are the indirect influences of the leadership on the employees' performance through work motivation.

In the reflective outer model, convergent and discriminant validity, and composite reliability are employed. according to Chin in Ghozali and Latan (2012), the value of the convergent loading factor for a confirmatory research is considered to be valid if it is $>0$., while for an explanatory research the value of the loading factor between 0.6 -0.7 may still be accepted. This present research used a minimal standard of 0.6 to measure the item validity.

\section{RESEARCH RESULTS AND DISCUSSION}

Contractor companies investigated to represent East Java province are from Blitar (24\%), Malang (40\%), Probolinggo (22\%) and Surabaya (14\%). Most contractors are companies under the medium classification (76\%), while the rest, $24 \%$ companies are under big companies. The number of medium companies is higher since in the real condition in the field, the proportion of development with higher project value is lower. As a result, the number of big contractors is lower than that of medium contractors. The difference of the contractor levels is needed in this present research to assure the better representativeness of the sample from the existing population. Research on leadership should cover all levels of contractors. Teamwork is very important since for project implementers, although a project is very difficult to work on, the difficulty will be easily handled if the teamwork is good and solid. The type of construction to work on at present is building $(55 \%)$, then roads $(13 \% \mathrm{~V})$, housing $(11 \%)$, port $(8 \%)$ and the rest is bus station, irrigation, water building and other building. Characteristics of companies based on their experiences may be categorized into young, old, and very old. Seventeen percent of the sampled company had five years experience; $34 \%, 6-19$ years; $43 \%, 11-25$ years; and 6\%, more than 25 years. In the hypothetical model, the position of work motivation is to mediate the relationship among the five leadership variables and the employees' performance. The hypothesis testing in the structural model is related to the result of the regression coefficient test for each path resulted as explained in Table 1.

The path coefficient of the authentic leadership in the work motivation of 0.063 was insignificant $(p>0.05)$. and in the employees' performance of -0.058 was also insignificant $(P>0.05)$. The application of the authentic leadership in higher intensity did not always improve the employees' work motivation and performance. Authentic leadership is a leadership which is less appropriate if it is applied in the scope of the relationship between the project implementers and the employees. The path coefficient of the combined leadership in the work motivation of 0.111 was significant (p.0.05) and in the employees' performance of 0.288 was also insignificant ( $p<0.05$ ). The application of the task-oriented leadership in a higher intensity may improve the employees' work motivation but it has not proved to directly improve the employees' performance. The path coefficient of people-oriented leadership in the employees' work motivation of 0.284 was significant $(p<0.05)$, but the coefficient in the employees' performance of 0.020 was insignificant $(p>0.05)$. The application of the people-oriented leadership style in a higher intensity may improve the employees' work 


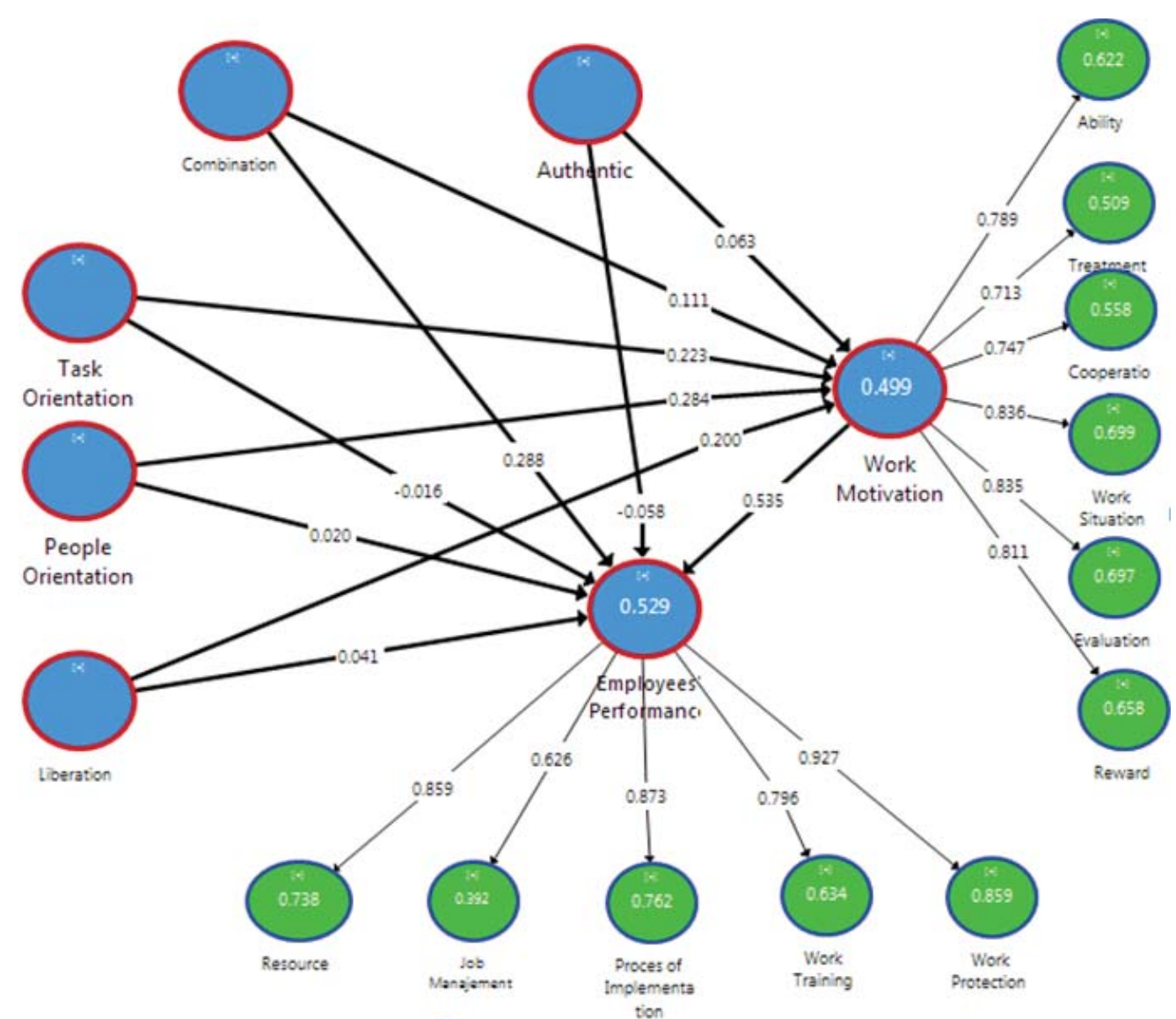

Figure 2: Results of the Path Coefficient Test

motivation but it has not proved to directly improve the employees' performance. The path coefficient of the liberalization leadership in the employees' motivation of 0.200 was significant $([>0.05)$, but the coefficient of it in the employees' performance of 0.041 was insignificant $(p<0.05)$. The application of the liberalization leadership in a higher intensity may improve the employees' work motivation but it has not proved to directly improve the employees' performance. The path coefficient of the employees' work motivation in the employees' performance of 0.535 was significant $(p<0.05)$. The employees with a higher level of work motivation will directly improve their performance.

The fit model may be measured using two fit model indices namely SRMR and fit model of $\left(R_{m}{ }^{2}\right)$. At the level of the fit model, Standardized Root Mean Square Residual

Table 1: Results of Regression Coefficient Test

\begin{tabular}{|c|c|c|c|c|}
\hline \multicolumn{2}{|c|}{ Influence } & \multicolumn{1}{c|}{} \\
\hline From & To & Standard Coeff. & t & p \\
\hline Authentic Leadership & Work motivation & & & \\
\hline Combination Leadership & Work motivation & 0.111 & 1.510 & 0.074 \\
\hline Task-oriented Leadership & Work motivation & 0.223 & 3.568 & 0.000 \\
\hline People-oriented Leadership & Work motivation & 0.284 & 2.413 & 0.012 \\
\hline Liberalization Leadership & Work motivation & 0.200 & 2.370 & 0.010 \\
\hline Work motivation & Employees' performance & 0.535 & 8.688 & 0.000 \\
\hline Authentic Leadership & Employees' performance & -0.058 & 0.671 & 0.220 \\
\hline Combination Leadership & Employees' performance & 0.288 & 3.641 & 0.000 \\
\hline Task-oriented Leadership & Employees' performance & -0.016 & 0.303 & 0.402 \\
\hline People-oriented Leadership & Employees' performance & 0.020 & 0.226 & 0.418 \\
\hline Liberalization Leadership & Employees' performance & 0.041 & 0.590 & 0.282 \\
\hline
\end{tabular}


(SRMR) value will be used. The SRMR value of lower than 0.08 was a good fit and it is a low good fit if its value is higher than 0.10 . The model proposed in this present research had the SRMR value of 0.088 , meaning that it is higher than 0.08 and lower than $0-10$. Therefore, it can be concluded that the model is a marginal fit namely it lies between poor fit and good fit.

Table 2: Results of the Fit Model Test Using the SRMR

\begin{tabular}{|c|c|c|c|}
\hline Index & Statistic & Good Fit Limit & Poor Fit Limit \\
\hline SRMR & 0,088 & Lower than 0,08 & Higher than 0,10 \\
\hline
\end{tabular}

The fit model may be measured from the model determination coefficient $\left(\mathrm{R}_{\mathrm{m}}{ }^{2}\right)$. The model determination coefficient is calculated using the whole determination coefficient $\left(R^{2}\right)$ existing in the model. The result of the $R^{2}$ calculation may be seen in Table 4.18. The $R^{2}$ value for the work motivation variable was 0.4 .99 . The value shows that the contribution of the five leadership styles to the work motivation was $49.9 \%$, while the rest is explained by other variables. The $\mathrm{R}^{2}$ value for the employees' performance was 0.529 . The value shows that the variation of the employees' performance explained by the leadership and work motivation is was. $9 \%$, the rest is explained by other variables.

\section{Table 3: Results of R-Square Measurement}

\begin{tabular}{|l|c|}
\hline Dependent Variable & $\mathbf{R}^{\mathbf{2}}$ \\
\hline Work Motivation & 0,499 \\
\hline Employees' performance & 0,529 \\
\hline
\end{tabular}

Hair et.al (2014) stated that in general the determination coefficient is low if its value is 0.20 , meanwhile in the results of this model the two coefficients were higher than 0.20 . Therefore, on the basis of the results of the fit model, the value is under a good category. The fit model can be calculated with the following formula:

$$
\begin{aligned}
& R_{m}{ }^{2}=1-(1-0,499)(1-0,529) \\
& R_{m}{ }^{2}=0,764
\end{aligned}
$$

The result of the calculation shows that the $R_{m}{ }^{2}$ value was 0.764 , meaning that this research model possesses a high fit model. The model accuracy of $76.4 \%$ explains that the contribution of the model to the explanation the structural relationship of the seven variables examined was $76.4 \%$ and the rest is explained by the other variables which are not involved in the model.

\section{DISCUSSION}

\section{The influence of leadership on employees' performance}

The results of the fit model explain that the improvement of the employees' performance is determined by how the project implementers lead the project. The leadership the implementers undergoes will involve many types of leadership because of various adjustments such as types and locations of the projects, types of employees, and the like. The suggested leadership for the area in East Java is the authentic leadership, a combination from transformational, transactional, and people-oriented leaderships.

According to Yin (1999), uniqueness of the construction industry is the existence of temporary employees (foremen, handymen, and workers) playing an important role in reaching the quality of a direct construction product. In managing projects, contractors in Indonesia in general still adhere to a work pattern of the foremen's system. Foreman is someone involved in a construction project serving as the supplier of handymen and workers and is the head of handymen and workers. Foremen, handymen and workers are contractors' freelance employees, where after a project is completed the work relationship between the contractor and the handymen and the workers will also end. Meanwhile according to Simamora (1995), employees should be viewed as an investment, therefore if they are developed and managed effectively they will give returns to the contractors in the form of greater productivity. It is expected that dependent employees may attain the goal of the project implementation namely proper cost, proper quality, and proper time.

Leadership as the defining factor of performance is also in line with result obtained by Yang et. al. (2011) in their research conducted in Taiwan. The contribution of combination leadership is one of the leadership choices appropriate with the construction project. Transactional and transformational leadership styles are needed where a team work is measured based on the team communication, team cooperation, and team cohesiveness, while the project performance valued using performance time schedule performance, quality performance, and stakeholders' satisfaction may be reached through strong team communication cooperation and greater team cohesiveness. Improving a leadership level, meaning the application of leadership proper with the need, may raise the relationship among team members.

Support from the leadership role to the employees' performance is also in line with the research results by Thite (2001) and Wang et.al. (2005). Transactional leadership style gives an emphasis on the contingent reward to meet performance goals. The transactional leadership style presents a traditional view of leadership focused on the contractual agreement between a leader and subordinators in terms of the expected performance as the reward for certain gifts.

Leadership competence should be possessed by each project implementer. According to Irawan et al (2012), the management of employees in contractor companies especially in the middle and high classes is less qualified so that it often happens that the process and the end results of project implementations deviated from the plans. This is influenced by the condition in the companies (internal factors: motivation, work environment, sal- 
ary increase) and out of the company (external factors: economic condition, technology, and business competition). As a result, it is necessary to have a proper strategy to improvement the management of the employees in the effort to improve the employees in the contractor companies.

Foster and Seeker (2001) stated that the causes of an employees' low quality/performance are his low knowledge and skills in doing the job assigned, low motivation to work better, and his low self-confidence in actualizing his ability to work. Simamora (1995) and Handoko (1994) stated that there are internal and external factors influencing any efforts to improve human resources (employees).

\section{The influence of work motivation on employees' performance}

The result of the fit model explains that employees' performance is also determined by the level of the employees' work motivation. Their performance has a stronger correlation with work motivation than with the leadership of the project implementers. This analysis explains that directly the role of work motivation is stronger. From the results of the analysis, it is found that reward and ability are two main indicators in explaining the high motivation showed by the employees.

The importance of the roles of work motivation is in line with the results of the research conducted by Verma (1996) that low motivation is the most often cause of project failures. Motivation is viewed as the main factor of the project management success. Similar finding is also met in Germann (2004) that less motivated managers and employees's tend to show low performance, although they have good management ability, technical skills and experiences in working on projects.

Besides motivation factor, project implementers should also pay attention to the de-motivation aspect namely a number of things that may decrease motivation. Turner et al (2008) in their research found that besides motivation, there are also work de-motivation (something decreasing the motivation). Concerning the various components of motivation, Oyedele (2010) identified three empirical factors of motivation that should be given more attention namely, support from the organization, success in implementing the design, and efforts to get recognition.

Great roles played by the employees' ability as the reflection of the existence of higher motivation are also found in the results of the research conducted by Kooij et al (2010). The impacts of motivation and de-motivation are depended upon individuals' personal factors such as ages, levels of education, sexes, cultures, experiences, jobs, levels of jobs and the like.

Meanwhile motivation and de-motivation factors identified in this present research will result in something different when they are applied individually or collectively since motivation and de-motivation occupy the same position. For instance, de-motivation factors such as in- justice in organization, stress due to projects, weak organizational cultures, negative leadership behavior and bad interpersonal relationship are identified by Oyedele (2010).

\section{The influence of leadership on work motivation}

The result of the fit model explains that the improvement of employees' motivation is determined by the leadership of the field implementers. The leadership employed by the field implementers will involve many types of leadership since the leadership style should be adjusted to various considerations such as types of project locations, employees, and others. The suggested leadership style adopted for the area in East Java is authentic leadership style, a combination among transformational, transactional and people-oriented leadership styles. From the analysis of this present research, it is found that the roles of the three leadership styles will promote the improvement of employees' ability and the optimal rewards given to the employees.

Leadership is a process of influencing others so that the others will follow and agree with what to do and how the process is effectively done and the process may facilitate individuals and collective to reach common goals (Dubrin, 2004; Dansereau et al., 1995).

The most general measure that may be used to understand leadership effectiveness is how an organization is able to apply a leadership successfully in doing tasks or in reaching its goals. Leaderships involves a social process in the form of intentional influence made by a person to others in the relationship structure of activities, relationships of groups or organization (Yukl and lepsinger, 2005).

People-oriented leadership as an important choice available for the field implementers is also expressed by Vera and Crossan (2004). Dealing with the roles of communication, Egri and Herman (2010) stated that an effective communicator may establish a commitment to the company vision and inspire the members of the organization to work towards the realization of the vision.

Concerning the need for planned changes in an organization, Battilanaa et all (2010) stated that the leadership role is focused on any activities dealing with communication, mobilization of the organization members, and with evaluation of the implementation of the planned organizational changes.

People-oriented leadership needs good communication ability. Field implementers shoul be able to communicate the need for changes, mobilize others to support changes, and evaluation the implementation of the changes. Three aspects are presented Battilanaa (2010) as the key activities for the relationship between leadership competence (namely the effectiveness of people- and task-oriented leadership behaviors) and the activities of planed organizational changes. The field implementers' communication ability not only tell the employees what to do, but also create a two-way communication, so that 
the whole team may understand and work effectively. Any dissatisfaction emerging from the existing situation should result in various efforts needed to make changes. Success in changes is influenced by a strong relation among the three components: people, process and technology (Cowandan Stradath, 2010).

The main role played by the implementers' leadership is to improve the employees' motivation. The level of this work motivation will give a great contribution to the changes of performance. High work motivation will become a sets of energetic power coming from either in or out of the individuals leading to work with the focus on the work management in order to improve performance (Kaulio, 2008).

The Influence of Leadership on Employees' Performance through Work MotivationThe results of the fit model explains that leadership gave direct effects on performance through work motivation. This relationship explains that the changes in performance is greatly determined by the power of motivation but, the improvement of motivation depends on the leadership adopted by the field implementers. In the three relationships, the leadership position is very important since it will give long impacts on the changes of employees' work motivation and performance. The result of this present research is in line with that from Nauman et al (2010) that the relationships among leadership, empowerment and services as an effective project management showed that the clime of empowerment had significant impacts on the concern with tasks, people and with services improvement, leadership behavior and with improvement of project performance.

The choice that task- and people-oriented leadership styles which are approaches to leadership forms on the basis of behaviors is also in line with the results found by Northouse (2004) and Nauman and lqbal (2005). Successful leadership is based on communication openness, conflict management, power and authority delegation, participation in decision making, problem solving though collaboration, guidance, and team work and time management, concern with tasks and with people in the project. They are greatly important for an effective project management.

Field implementers should be brave in positioning themselves as the leaders who are fully responsible for the completeness of the projects. It is said in traits theories that as a leader, one should be able to possess certain characteristics or personalities that differentiate leaders from non leaders (Judge et al, 2002). Field implementers should have specific behaviors that may distinguish effective and ineffective leaders viewed from various dimensions. They should have high awareness of various tasks and responsibility as leaders. Kozlowski and Ilgen (2006) stated that common leadership needs common understanding on knowledge, ability skills, and behavior needed to complete tasks on hand and common decision where team members play roles in taking over lead- ership roles. Barsade (2002) showed that a team work with positive emotional condition influences a better level of cooperation, is able to reduce conflicts and possesses a perception of higher performance of tasks. A similar perception is given by Pscolosolido (2002) that the emergence of a leader in a group may be determined by anyone who is able to manage proper emotion of a group. Barsade (2002), Bartel and Saavedra (2000), Tiedens, et. al (2004) presented an opinion that the increase of interdependence, which is part of task implementation, is emotionally influenced by group members.

Experience and level of education possessed by field implementers will help them explain what should be done by employees in their jobs (Avolio et. al., 2000). The leaders' ability in explaining this task is greatly related to work motivation that will be resulted in (Kerzner, 2000). The importance of clear goals is to reach an optimum performance of a project. The project goal should be realistically determined by paying attention to the available resources (Pinto, 2000).

The role of motivation in promoting performance should also be offset by paying attention to the de-motivation factors. Germann (2004) stated that without motivation, the most talented person will not be able to show or give his/her potency. Oyedele (2012) reminded that there are seven factors of de-motivation causing the decrease of individual performance namely organizational injustice, stress caused by projects, team dysfunction or low team cooperation, weak organizational cultures, and inefficient work. Colquitt (2001), Rose, and Manley (2011) offered some suggestions to avoid or omit de-motivation factors namely justice and equality in resources distribution, justice in procedures, justice in the obedience to rules, justice in process, justice in decisions leading to results, and justice in interactions (respect, dignity, politeness) that should be done by the employees in their work place when they face other

\section{CONCLUSION}

From the results of the analysis and discussions above, the following conclusions would drawn. The leadership of the field implementers, especially their combination leadership style significantly influence employees' performance. Work motivation significantly influence on employees' performance. This relationship explains that the improvement of employees' performance is determined by the work motivation of the employees. Leadership significantly influences work motivation. Three leadership styles adopted by the field implementers in order to be able to improve employees' motivation quickly are task-oriented leadership, people-oriented leadership and liberalization leadership. Task-oriented leadership and people-oriented leadership indirectly influence employees' performance through motivation. This relationship explains that the changes in performance is much more determined by the power of motivation, but the improvement of motivation is dependent upon the leadership 
style employed by the field implementers. In the three relationship, the position of leadership becomes very important since it will give great influence on changes in employees' work motivation and performance.

\section{RECOMMENDATION}

Combination leadership gives some influences on employees' performance. But this combination leadership is ineffective in improving work motivation, but it may complement the roles of motivation in improving employees' performance. Leadership, in general, influences the employees' work motivation. The application of the task-oriented leadership, the people-oriented leadership and the liberation leadership is more sensitive in improving employees' work motivation. The three leadership styles indirectly influence employees' work performance through motivation. This relationship explains that changes in performance are much determined by the power of motivation but the improvement of motivation is dependent upon the leadership style adopted by field implementers.

\section{REFERENCES}

Abdel-Razek R. H, Elshakou H. A.M, Hamid. A.M, (2007)."Labor productivity: Benchmarking and variability in Egyptian projects". International Journal of Project Management 25; 189-197.

Ali, A., Bin, L.Z., Piang, H.J., \& Ali, Z., (2016). "The Impact of Motivation on the Employee Performance and Job Satisfaction in IT Park (Software House) Sector of Peshawar, Pakistan". International Journal of Academic Research in Business and Social Sciences. 6 (9)

Apak, S., \& Gümüş, S. (2015). "A Research About The Effect Of The Leadership Qualities Of Public Administrators On The Motivation Of The Employees". Procedia - Social and Behavioral Sciences. 210 : 368 - 377

Atkinson A, Weterhouse J, and Wells R (1997). "A Stakeholder Approach to Strategic Performance Measurement”. Sloan Management Review, 38(3), p. 25-37.

Avolio, B. J., Kahai, S., \& Dodge, G. (2000). "E-leadership and its implications for theory, research, and practice". The Leadership Quarterly, 11, 615-670.

Avolio, B., \& Gardner, W. (2005). "Authentic leadership development: Getting to the root of positive forms of leadership". The Leadership Quartely, 16, 315-338.

Avolio, B.J., Gardner, W.L., Walumbwa, F.L., May, D.R., (2004). "Unlocking the mask: a look at the process by which authentic leaders impact follower attitudes and behaviors". Leadership Quarterly. 15, 801-823.

Baron, R. M. and Kenny, D. A. (1986). "The Moderator-Mediator Variable Distinction in Social Psychological Research: Conceptual, Strategic, and Statistical Considerations". Journal of Personality and Social Psychology, 51(6), 1173-1182

Barsade, S. G. (2002). "The ripple effect: Emotional contagion and its influence on group behaviour". Administrative Science Quarterly, 47, 644-675.
Bartel, C. A., \& Saavedra, R. (2000). "The collective construction of work group moods". Administrative Science Quarterly, 45, 197-231.

Battilanaa, J., Gilmartinb, M., Sengulc, M., Pached, C, A., Alexandere, J, A. (2010). "Leadership competencies for implementing planned organizational change". The Leadership Quarterly 21. 422-438.

Bernstein HM (2007). "Measuring Productivity in Construction: Improving Business Performance". Dodge Sweets Architectural Record ENR Regional Publications.

Bono, J. E., \& Judge, T. A. (2004). "Personality and transformational and transactional leadership: A meta-analysis". Journal of Applied Psychology, 89, 901-910.

Colquitt, J.A., (2001). On the dimensionality of organizational justice: "a construct validation of a measure". Journal of Applied Psychology 86, 386-400.

Dansereau, F. (1995). A dyadic approach to leadership: "Creating and nurturing this approach under fire". The Leadership Quarterly, 6, 479-490.

DeTreville, S., Antonakis, J., (2006). "Could lean production job design be intrinsically motivating? Contextual, configural, and levels-of-analysis issues". Journal of Operations Management 24 (2), 99-123.

DuBrin, A.J., (2004). Leadership Research Findings, Practice, and Skills, 4th ed. Houghton Mifflin Company, Indianapolis.

Egri, C. P., \& Herman, S. (2000). Leadership in the North American environmental sector: "Values, leadership styles and contexts of environmental leaders and their organizations". Academy of Management Journal, 43, 571-604.

Elizabeth Boye Kuranchie-Mensah \& Kwesi Amponsah-Tawiah. (2015). "Employee Motivation and Work Performance: A Comparative Study of Mining Companies in Ghana". Journal of Industrial Engineering and Management. 9 (2) : 255-309

Foster, Bill, Seeker, Karen, R., (2001), Pembinaan untuk Meningkatkan Kinerja Karyawan, PPM, Jakarta.

Gardner, W. L., Avolio, B. J., Luthans, F., May, D. R., \& Walumbwa, F. (2005). "Can you see the real me?" A selfbased model of authentic leader and follower development. The Leadership Quarterly, 16, 343-372.

Germann, M., (2004). "Influence of project managers on the motivational factors of a project team". Paper Presented at the 13th International Conference on Management of Technology IAMOT, Washington, DC. April.

Ghaffari, S., Shah, I.M., Burgoyne, J., Nazri, M., Salleh, J.R. (2017). "The Influence of Motivation on Job Performance: A Case Study at Universiti Teknologi Malaysia". Australian Journal of Basic and Applied Sciences, 11(4) : 92-99 
Ghaffari, Sara, Shah, Ishak Mad, Burgoyne, John, Nazri, Muhammad, Shalleh, Jalal Rezk. (2017). "The Influence of Motivation on Job Performance: A Case Study at Universiti Teknologi Malaysia". Australia Journal Basic and Applied Sciences, 11 (4) : 92- 99.

Ghozali, I. Latan, H. (2012). Partial Least Square: Konsep, Teknik dan Aplikasi SmartPLS 2.0 M3. Semarang: Badan Penerbit Universitas Diponegoro.

Ghozali, Imam. 2011. Aplikasi Analisis Multivariate Dengan Program SPSS. Semarang: Badan Penerbit Universitas Diponegoro.

Graves, L.M., \& Sarkis, J. (2018). "The Role Of Employees' Leadership Perceptions, Values, And Motivation In Employees' Provenvironmental Behaviors". Journal of Cleaner Production.

Hackman R, Oldham G. (1980). Work redesign. Reading, MA: Addison-Wesley;

Hair Jr. J. F, Hult G. T., Ringle C. M., \& Sarstedt M. (2014). A Primer on Partial Least Squares Structural Equation Modeling (PLS-SEM). California: SAGE Publication.

Hair, J. F., Black. W. C., Babin. B. J.; and Anderson. R. E. (2010), Multivariate Data Analysis, 7th ed. Pearson Prentice Hall, New Jersey

Hair, J.F. (2006). Multivariate Data Analysis. Edisi 5. Jakarta: Gramedia Pustaka Utama.

Handoko, T. Hani. (1994). Manajemen Personalia Dan Sumber Daya Manusia. Yogjakarta : BPFE yogjakarta.

Hartono, J. \& Abdillah, W. (2009). Konsep \& Aplikasi PLS (Partial Least Square) untuk Penelitian Empiris. Yogyakarta: BPFE

Hyvari, I., (2006). "Project management effectiveness in project-oriented business organizations". International Journal of Project Management 24. 216-225

Ilies, R., Morgeson, F. P., \& Nahrgang, J. D. (2005). "Authentic leadership and eudaemonic well-being: Understanding leader-follower outcomes".The Leadership Quarterly, 16, 373-394.

Irawan,D; Riman; Mochtar,I,S; Utomo,C, (2012), "The Measurement Model For Freelance Worker Performance Employed By Middle Class Contractor To Improve The Quality Of Building", Journal of Basic applied scientific research, Vol 2, Part II, july TextRoad Publication.

Judge, T. A., Bono, J. E., llies, R., \& Gerhardt, M. W. (2002). "Personality and leadership: A qualitative and quantitative review". Journal of Applied Psychology, 87,765-780.

Kaulio, M.A., (2008). "Project leadership in multi-project settings: Findings from a critical incident study", Interna tional Journal of Project Management 26. 338-347

Kerzner, H., (2000). Project Management: A Systems Approach to Planning, Scheduling, and Controlling. John Wiley, USA.
Kloppenborg, T.J., Petrick, J.A., (1999). "Leadership in project life cycle and team character development". Project Management Journal. 30 (2), 8-13.

Kooij, D., DeLange, A.H., Jansen, P.G.W., Kanfer, R., Dikkers, J.S., (2010). "Age and work-related motives: results of a meta-analysis". Journal of Organizational Behavior 31 (8), 1111-1136.

Kozlowski, S. W. J., \& Ilgen, D. R. (2006). "Enhancing the effectiveness of work groups and teams". Psychological Science in the Public Interest, 7, 77-124.

Lloyd-Walker, B. \& Walker, D. (2011). "Authentic leadership for 21st century project delivery". International Journal of Project Management, 29, 383-395.

McClelland, D., (1961). The Achieving Society. The Free Press, New York.

Milgunova, V. I., \& Anoshina, F. I. [2018]. Regional management of building complex competitiveness based on the modeling of integration process. Journal of Applied Engineering Science, 16(1), 142-152.

Muller, R. \& R. Turner, (2009), "Leadership competency profile of seccessful project managers", International Journal of Project Management .

Müller, R., Turner, J.R., (2007). "Matching the project manager's leadership style to project type". International Journal of Project Management 25 (1), 21-32.

Mustaqim. (2016). "The Influence of Leadership Styles and Motivation of Employees Job Satisfaction". International Journal of Economics and Finance. 8 (10)

Naile, I. \& Selesho, J.M. (2017). "The Role of Leadership in Employee Motivation". Mediterranean Journal of Social Sciences. 5 (3)

Nauman, S., Iqbal, S., (2005). "Challenges of Virtual Project Management in Developing Countries". Published in IEEE International Engineering Management Conference. NewFoundland, Canada.

Nauman, S., Khan, M.A., Ehsan, N., (2010). "Patterns of empowerment and leadership style in project environment". International Journal of Project Management 28; 638-649.

Ng, S. Thomas, Tang, Ziwei, (2010), "Labour-intensive construction sub-contractors: Their critica”, International Journal of Project Management, 28:732-740

Northouse, P.G., (2004). "Leadership: Theory and Practice". Sage, Thousand Oaks, CA.

Oyedele, L.O., (2010). "Sustaining architects' and engineers' motivation in design firms: an investigation of critical success factors". Engineering Construction and Architectural Management 17 (2), 180-196.

Oyedele, L.O., (2012). "Analysis of architects' demotivating factors in design firms" International Journal of Project Management 20 (2) 1-13

Pinto, J.K., (2000). "Understanding the role of politics in successful project management". International Journal of Project Management,;18(2):85-91. 
Prabowo, T.S., Noermijati, Irawanto, D.W. (2017). "The Influence Of Transformational Leadership and Work Motivation On Employee Performance Mediated By Job Satisfaction". Journal of Applied Management (JAM). 16 (1)

Rawung, F.H. (2013). "The Effect of Leadership on the Work Motivation of Higher Education Administration Employees (Study at Manado State University)". IOSR Journal of Business and Management (IOSR-JBM). 15 (1) 28-33

Rose, T., Manley, K., (2011). "Motivation towards financial incentive goals on construction projects". Journal of Business Research 64 (7), 765-773.

Sansone, C., Harackiewicz, J., (2000). Intrinsic and Extrinsic Motivation-the Search for optimal Motivation and Performance. Academic Press, San Diego, CA.

Shahzadi, I., Javed, A., Pirzada, S.S., Nasreen, S., \& Khanam, F. (2014). "Impact of Employee Motivation on Employee Performance". European Journal of Business and Management. 6 (23)

Simamora, H., (1995), Manajemen Sumberdaya Manusia, STIE YKPN, Edisi I, September, Yokyakarta.

Soekiman, A. Soekimana, K. S. Pribadib, B.W. Soemardib,R.D.Wirahadikusumah,(2011) "Factors Relating to Labor Productivity Affecting the Project Schedule Performance in Indonesia". Procedia Engineering 14. 865873.

Sougui, A.O., , A.T., \& Hassan, H.M.H. (2015). "The Impact of Leadership Styles on Employees' performance in Telecom Engineering companies". Australian Journal of Basic and Applied Sciences, 8(4)

Thite Mohan., (2000). "Leadership styles information technology projects". International Journal of Project Management 18, 235-241.

Thite, M., (2001). "Leadership styles in information technology projects". International Journal of Project Management 18 (4), 235-241.

Tiedens, L. Z., Sutton, R. I., \& Fong, C. T. (2004). "Emotional variation in work groups: Causes and performance consequences". In L. Z. Tiedens, \& C. W. Leach (Eds.), The social life of emotions (pp. 164-186). New York: Cambridge University Press.

Toor, S.-u.-R., Ofori, G., (2008). "Leadership for future construction industry agenda for authentic leadership". International Journal of Project Management 26 (6), 620630.

Turner, J.R., Műller, R., Dulewicz, V., (2009). "Comparing the leadership styles of functional and project managers". International Journal of Managing Projects in Business. 2 (2), 198-216.

Turner. R, Huemann.M, Keegan.A. (2008). "Human resource management in the project-oriented organization: Employee well-being and ethical treatment". International Journal of Project Management 26; 577-585.
Veliu, L., Manxhari, M., Demiri, V., \& Jahaj, L. (2017). "The Influence Of Leadership Styles On Employee's Performance". Vadyba / Journal of Management, 31 (2), 59-69

Vera, D., \& Crossan, M. (2004). "Strategic leadership and organizational learning". Academy of Management Review, 29(2), 222-240.

Verma, V.K., (1996). "Human Resource Skills for the Project Manager: The Human Aspects of Project Management", Volume Two. Project Management Institute, Upper Darby, PA.

Wang, E., Chou, H.W., Jiang, J., (2005). "The impacts of charismatic leadership style on team cohesiveness and overall performance during ERP Implementation". International Journal of Project Management 23 (3), 173-180. Yang, R.L., Huang, F. C., Wu, S. K., (2011). 'The association among project manager's leadership style, teamwork and project success". International Journal of Project Management 29. 258-267.

Yukl G, Lepsinger R. (2005). "Why integrating the leading and managing roles is essential for organisational effectiveness". Org Dyn 34(4):361-75.

Yukl, G. (1999). "An evaluation of conceptual weaknesses in transformational and charismatic leadership theories". The Leadership Quarterly, 10, 285-305.

Paper submitted: 28.05.2019.

Paper accepted: 08.08.2019.

This is an open access article distributed under the CC $B Y-N C-N D 4.0$ terms and conditions. 